\title{
Process Innovation in Local Governments: an empirical study of its continuous improvement efforts
}

\section{A Inovação de Processos nas Administrações Locais: um estudo empirico de seu esforço de melhoria contínua}

\section{Innovación de Procesos de Administraciones Locales: un estudio empirico sobre su esfuerzo de mejora continua}

\section{Manuel Francisco Suárez-Barraza ${ }^{1}$}

Received on December 12, 2011 / Approved on June 12, 2013

Responsible Editor: João Maurício Gama Boaventura, PhD

Evaluation process: Double Blind Review

\section{ABSTRACT}

This article seeks to explore and understand how the process innovation (PI) is being applied in Spanish local administrations over the years. Therefore, we have conducted a qualitative study using a case study research method in four Spanish municipalities, using the following strategies for data gathering: direct observation, participatory observation, document analysis, and semi-structured in-depth interviews. Theories or schools of thought on which the study is based include Public Management and Operations Management in the field of Process Innovation. The findings indicate that the implementation of the PI in local governments is conducted through a series of evolving stages and improvement activities. The impact in the different processes and public services has been beneficial in terms of internal performance and satisfaction to the citizen. Therefore, when such public institutions have had the will and the commitment of politicians and senior technicians to innovate their work processes, such effort has been steadily practiced over the years. It is one of the first studies to explore the application of Process Innovation in public management of local governments.

Keywords: Innovation. Continuous improvement. Process innovation. Public management. Local governments.

\section{RESUMO}

O presente artigo busca explorar e compreender como se aplica a Inovação de Processos (IP)

1. Ph.D. in Management Science for ESADE Business School. Professor at EGADE Business School and Visiting Professor at ESADE Business School of Lean-Kaizen.

Address of the author: Avenida Carlos Lazo No.100, Col. Santa Fe, Delegación Álvaro Obregón, Mexico D.F, Mexico. C.P. 01389. Tel. +52 (55) 9177-8000. Ext. 7928 
em administrações locais espanholas ao longo dos anos. Para isso, realizou-se um estudo qualitativo com o método de caso de quatro prefeituras (ayuntamientos) espanholas, utilizando para a coleta de dados as seguintes estratégias: observação direta, observação participativa, análise documental e entrevistas semiestruturadas em profundidade. As teorias ou escolas de pensamento sobre as quais o estudo é sustentado incluem a administração pública e a gestão de operações em seu campo de inovação de processos. Os resultados indicam que a aplicação de IP nos governos locais é apresentada por meio de uma série de etapas evolutivas e atividades de melhoria. O impacto ocorrido nos diferentes processos e serviços públicos foi benéfico em términos de desempenho interno e satisfação ao cidadão. Portanto, quando tais instituiçóes públicas contaram com a vontade e o compromisso por parte dos políticos e diretivos técnicos para inovar seus processos de trabalho, tais esforços foram levados à prática de maneira sustentável ao longo dos anos. Trata-se de um dos primeiros estudos a explorar a aplicação da inovação de processos na gestão pública dos governos locais.

Palavras-chave: Inovação. Melhoria contínua. Inovação de processos. Administração pública. Governos locais.

\section{RESUMEN}

En el presente artículo se busca explorar y comprender cómo se aplica la Innovación de Procesos (IP) en las Administraciones locales españolas a lo largo de los años. Para ello, se realizó un estudio cualitativo con el método del caso de cuatro ayuntamientos españoles, utilizando para la recolección de datos las siguientes estrategias: observación directa, observación participativa, análisis documental y entrevistas semiestructuradas en profundidad. Las teorías o escuelas de pensamiento sobre las que se sostiene el estudio son la de Gestión Pública y la Gestión de Operaciones en su campo de Innovación de Procesos. Los resultados nos indican que la aplicación de la IP en los gobiernos locales se presenta a través de una serie de etapas evolutivas y actividades de mejora. El impacto que ha tenido en los diferentes procesos y servicios públicos ha sido beneficioso en términos de desempeño interno y satisfacción del ciudadano. Por lo tanto, cuando dichas instituciones públicas han recibido la voluntad y el compromiso de los políticos y directivos técnicos para innovar sus procesos de trabajo, dicho esfuerzo se ha llevado a la práctica de manera sostenida a lo largo de los años. Se trata de uno de los primeros estudios en explorar la aplicación de la Innovación de Procesos en la gestión pública de los gobiernos locales.

Palabras clave: Innovación. Mejora continua. Innovación de procesos. Gestión pública. Gobiernos locales.

\section{INTRODUCTION}

In the early 1990's, a new management movement and approach came up in American universities with the main focus on management and improvement of organizations' work processes. Such expression has created enthusiasm both in the business and in the academic fields. The reason for such an enthusiasm was the pursuit for answers to the question of how processes could contribute to reduce the fragmentation and excessive departmental structures of work methods, in order to obtain a better lateral coordination and communication capacity within the organizations (GARVIN, 1998).

The origin of this new management approach is mainly found in the industrial manufacturing companies, although, as the result of the pressures from the new economic, financial and social scenario on the organizations worldwide, some sectors of the public administration in Spain have started to look at a new way of working focused on the horizontality and on the transversality (GINER-RODRÍGUEZ, 1998). In view of this scenario, the logic of modernization and improvement of the sustainable public administration in terms of effectiveness and efficacy (synonym of management capacity) was obtained by some Spanish local governments at 
the end of the 1980's and the early 1990's, with the sole aim of facing this changing factors, which made them slowly recover the legitimacy possibly lost before the citizens (OLÍAS DE LIMA, 2007).

According to Díaz Méndez (2007), it seems that with the routinely increase of political, social (more demanding citizens), and economic (budget reductions and increasing tax pressure) pressures of recent years, more local governments in Spain have increased their awareness, joining this kind of innovative initiatives. Furthermore, those managing to keep their improvement efforts for various years, to integrate them to the routine management, have become true archetypes for those local administrations that are starting or intend to start their innovation efforts (FERRÉBARGALLO, 2007). In concrete terms, the core purpose on which this study is based and that help us structuring this article is to understand how the Process Innovation (PI) is being applied in Spanish local administrations over the years. For such a purpose, two basic research questions were made:

- How the Process Innovation is presented in a framework of Total Quality Management application in Spanish local Administrations?

- What is the impact of the Process Innovation in public services in the framework of the Total Quality Management application in Spanish local Administrations?

\section{CONCEPTUAL FRAMEWORK}

\section{I Process innovation: concept and dimensions}

In the beginning of the second decade of the 21 st Century, the word processes starts to be part of the routine language of organizations. In fact, in any business sphere where it is applied and implemented, it is regarded as a synonym to attain the so desired operational efficiency within organizations. Different authors have tried to define the concept, such as Harrington (1991), one of the pioneers of the theme who defines it as "any activity or set of activities that accesses an entrance, adds value to it and provides an exit to an internal or external client. Processes use the organization resources to provide a final result". Davenport (1993), another author recognized in this field, indicates that a process is "a specific ordering of work activities throughout time and space, which has a beginning and an end, and with a clear definition of entrances and exits in its action structure". Basically, following both classical definitions, a process is a set of logical activities that transforms elements of entrance (inputs) into exits (outputs), which are delivered to a client that is the receptor of them.

It is possible to track the origin of process innovation (PI) back in the development of the Scientific Administration school, whose main representative was Frederick W. Taylor. However, as already mentioned, it was only in the 1990's when the word processes started to get the importance as a possible approach to the improvement and innovation within organizations. Thus, the PI is defined by Harrington (1991, p. 20-21) as: "a systematic methodology developed to help an organization to significantly progress in the way it operates its processes". Therefore, along the years and as the result of the diffusion of the concept of processes, there was an "explosion" in the academic and management literature not only about this topic, but also about those approaches required to improve them, such as: Kaizen (continuous improvement), redesign and/or innovation of processes, and the Reengineering of Business Processes. At least three dimensions of the Process Innovation were identified: The incremental PI or Kaizen; 2) The PI of the process redesign type; and the 3) Business Process Reengineering. Each of them is differentiated according to the degree or type of innovation (incremental or radical) executed; its reach (for functional or interdepartmental processes); the costs and times of application, and the expectations and risks of the result to be obtained (MACDONALD, 1995; SALGUEIRO, 1999). The aforementioned is shown in detail in the following chart: 


\begin{tabular}{|l|c|c|c|}
\hline & $\begin{array}{c}\text { Incremental } \\
\text { Kaizen }\end{array}$ & $\begin{array}{c}\text { Process } \\
\text { redesign }\end{array}$ & $\begin{array}{c}\text { Process } \\
\text { reengineering }\end{array}$ \\
\hline Degree of change & Small incremental changes & $\begin{array}{c}\text { Intermediary } \\
\text { changes } \\
\text { changes }\end{array}$ & Every type of process \\
\hline Reach & $\begin{array}{c}\text { Functional and/or } \\
\text { operational processes }\end{array}$ & Interdepartmental processes & High \\
\hline $\begin{array}{l}\text { Implementation } \\
\text { costs }\end{array}$ & Low & Intermediary & High \\
\hline $\begin{array}{l}\text { Expectation of } \\
\text { results }\end{array}$ & Low & Intermediary & \\
\hline
\end{tabular}

CHART 1 - Dimensions of the process innovation

Source: the author.

The purposes or the impact of the Process Innovation within organizations go beyond the mere integration as part of the company's strategy. Its benefits in the operations management can be directly quantified within organizations. A summary of what the literature indicates is presented as follows: a) resources used can be better evaluated and reduced; b) it becomes easier to reduce operational costs; c) works as a method to understand the work (how entrances - inputs - are transformed into exits - outputs-); d) provides a mechanics to find, solve and prevent problems and errors in the work (improvement areas); e) it is possible to reduce process times; f) work measurement can be established in a more effective and systematic way; g) it allows to better orient the organization towards the customer; $h$ ) provides a systemic and transversal vision of the organization; and i) can benefit the participation, communication and team work among employees and managers (CHANG. 1995; HAMMER, 2007; LEE; DALE, 1998; ZAIRI, 1997).

\subsection{Total quality management in the public sphere}

The Total Quality Management (TQM) has spread in nearly all the industrialized countries, and its popularity within the public sphere has enormously increased since the late 1980's (STRINGHAM, 2004). It was consolidated within this perspective until becoming the main modernization alternative in the public sector due to its strong emphasis on the improvement and on the quality of public services (MILAKOVICH, 1991). In regard to this, two works contributing to this spread and to the possible popularity of the theme were the works of Osborne and Gaebler (1994) and of Barzelay and Armajani (1992).

Furthermore, the literature indicates that, due to the eclectic and ambiguous nature of the TQM, it was differently used depending on the circumstances of the country where it was applied. In countries where the New Public Management (NPM) was used, the United Kingdom, Australia, Canada, Holland and New Zealand, the main focus was on the strategic planning and management techniques, financial management control, human resources control and management (through the civil career service), Citizen's Charters, and techniques of team work (POLLIT, 1994), in addition to a remarkable emphasis on innovation and reengineering of processes (BPR), through information technologies (IT), and radical changes (MCADAM; DONAHY, 1999).

In the United States of America (USA), the model of the National Performance Review (NPR) of the federal government, previously described, was used, being spread through the Federal Institute of Quality (already closed) in the late 1980 's and early 1990 's to local governments and agencies (SENSENBRENNER, 1991). In the USA, the TQM principles are still currently being used in various levels of the government (STRINGHAM, 2004). Also, the literature reports various study cases of applications and techniques related to the TQM in local Administrations of 
the United States of America (BERMAN; WEST, 1995; MILAKOVICH, 1991). In fact, in a study conducted by Berman and West (1995, p. 64), it is inferred that "approximately $11 \%$ of the American cities surveyed with more than 25,000 residents have applied some TQM effort".

In Latin America, the efforts have been also promising, although to a smaller degree and many years later than in the USA and the United Kingdom (MOYADO-ESTRADA, 2002). For this reason, when exploring the literature in Latin America, only some few specific references to the TQM and process innovation were found (ALBIZU; OLAZARÁN; SIMÓN, 2004; ANDREU; RICART; VALOR, 1996; SUÁREZBARRAZA; RAMIS-PUJOL, 2010). The first of them is the reference to Andreu, Ricart and Valor (1996) that indicates that to allow the application of process innovation it is necessary to have a TQM process supported by the Information Technology (IT) efforts, which along with the organizational change are considered as keycatalyzers in the efforts of process innovation. To Albizu, Olazaran and Simón (2004), the TQM projects have been mainly related to the organizational change: organizational structure, and organization and contents of the work. These authors say that on applying a process innovation methodology, the change is not as radical as the one considered in the orthodox model of the Process Reengineering (HAMMER; CHAMPY, 1993), considering that such TQM efforts can exist simultaneously with the methodology of continuous improvement and process innovation. At last, Suárez-Barraza and Ramis-Pujol show an example of TQM application through the continuous improvement to reduce the time of a staff hiring service process in a human resources office of the public administration in Mexico, showing the connection between both focuses.

\subsection{Process innovation efforts in local administrations}

Since the pioneer works of Deming (1986), the importance of process innovation within the framework of the total quality management in government services has been highlighted. For this reason, the trend and the positive impacts on the improvement of public services by applying PI in certain government organisms have been consolidating this management approach to the public business, until making it a feasible alternative to the innovation efforts in advanced democracy countries. However, a local government (ayuntamiento) is a complex and dynamic public organization, which at first glance seems not to be prone to create a management change because of its political component, because of its heterogeneous public services, and also because of the different roles played by the citizens in their relationship with the local Administration ${ }^{1}$ (SWISS, 1992).

From our viewpoint, the need of local Administrations to continue innovating with management models according to the changes of this new scenario is preponderant. The society served by the local Administration has become more dynamic and complex, creating fast and turbulent processes of change (FARAZMAND, 2001). New factors have come up (economic, social, political, technological, cultural, managerial, and also new knowledge and information), pushing European and Spanish local Administrations to experiment deep transformations in their public management, as a response to such pressures from this extremely shaken environment (MARTÍN-CASTILLA, 2005). It is thus indispensable that any attempt of the local Administrations to apply the PI to be conducted through a transversal or horizontal focus, breaking through the governmental inertia of departments and functional areas, the socalled "Taifa reigns", which transform the public work in a chain of superfluous, unnecessary, bureaucratic activities that, at the end of the day, are a burden and a waste to the whole municipal management. From such conception, we infer that all those Spanish local Administrations (the ones closer to the citizen) that have embraced such models have assumed that the notion of innovation in their municipal management is focused on the results of processes - the provided service valuing the user (the desired outcomes 
affecting the citizen) who uses it, i.e., the focus is on the management and innovation of processes producing public services, to actually attain an impact in terms of results and responses to the social needs (FEDERACIÓN ESPAÑOLA DE MUNICIPIOS Y PROVINCIAS, 1999).

In Spain, some local Administrations have already started their way towards a sustainable innovation. The Federation of Municipalities and Provinces (FEMP) and the Spanish Association for the City - AEC (2005) have reported that the implementation of such kind of models or systems related to the quality and to the PI has started to slowly grow. According to their study $^{2}$, only approximately $5 \%$ of the local Administrations have some kind of ISO 9000 quality certificate in any of their processes; while approximately $10 \%$ have published a Service Letter; approximately $2 \%$ have tried another type of improvement and innovation effort, such as: improvement teams, process redesign, Kaizen, problem solving methodologies, etc.; and only $1 \%$ uses self-evaluation models related to quality and excellence awards, such as: the EFQM ${ }^{3}$, the Latin American Award or the citizenship model. However, there are still lots to do considering the great number of local Administrations with resources and possibilities to conduct a PI effort.

The local governments that have decided to start this innovation path since the early $1990^{\prime} \mathrm{s}^{4}$ have developed a new conception in the way they manage their organizations, from improving the quality of the services provided; executing their processes in a more effective and efficient way, to reduce the costs of the municipal management (money saving); until keeping the principle of legality, without being rigid, and guiding and approximating political decisions to the citizens through process standards in order to keep the current social services as higher as possible.

In view of the aforementioned context, it is essential to understand how local governments have managed to sustain the Process Innovation effort along all those years, in a context $s$ o characteristics as the local sphere one. The concept of "Sustainability", simply understood as the maintenance of improvements implemented through a PI effort along the years, has been studied in private sector organizations in recent years (mainly in the manufacturing industry) (BATEMAN, 2005). The works of Harkness, Kettinger and Segars (1996) argue that the transformation path followed by an organization that only creates utilities, to become a global organization that innovates and improves its processes, is a set of evolving stages composed of the application of the improvement activities, techniques and tools that integrate and are part of them. In this same order of ideas, other researchers have found the empirical evidence through their study cases, showing that the success achieved by some organizations in their improvement effort is closely related to the historical evolution of such effort, i.e., the development of intermediary evolving stages of a serious and systemic implementation of the PI or of the TQM (HARKNESS; KETTINGER; SEGARS, 1996; PRAJOGO; SOHAL, 2004). Such studies provide a basis to say that only through a sustainable PI or TQM effort throughout time, it is possible to achieve tangible benefits for the organization in terms of effectiveness of the organization activities.

From such researches, various models have come up to explain the term and characterize it (BATEMAN; DAVID, 2002; BESSANT; CAFFYN, 1997; PALMBERG; GARVARE, 2006). However, in the sphere of the public sector, the literature shows few studies of the sustainability aspect (LOOMBA; SPENCER, 1997; SUÁREZBARRAZA; MIGUEL-DÁVILA, 2009), and when specifically analyzing the references focused on Spanish local Administrations, what is found in the literature is insufficient, not to say inexistent.

The aforementioned described changing and turbulent environment continues to pressure those Spanish local Administrations nowadays. In fact, despite the improvement efforts conducted along all those years by some of them, citizens, public servants, employees, associations, 
politicians and other stakeholders of such local Administrations keep saying that there are still lots to do, and that maintaining the achievements is the least commitment needed to face the pressure of the external and internal environments (DÍAZMÉNDEZ, 2007).

\section{METHODOLOGY}

The research methodology used to develop this study is of the qualitative type, through the study case method (YIN, 2003). This type of methodological design is conceived to elaborate a theory from the findings of the analyzed study cases (EISENHARDT, 1989). For such reason, the theory construction process is an understanding of "how" and "why" a local Administration has managed to apply its PI effort throughout the years. The analysis of each case allows us to use multiple information sources, reducing the possibility of data loss, and increasing the validity of such data (YIN, 2003).

In concrete terms, the research was conducted in four Spanish local Administrations (see Chart 2), comparable among each other because they have a population of over 40,000 residents, having conducted an effort in some type of PI during at least 10 years (having traceability memories), and having the financial and human resources to develop them. Furthermore, some of them are exceptional highlights for having obtained national and/or international awards, and quality and/or excellence certificates.

\begin{tabular}{|c|c|c|c|c|}
\hline Local Administration & Pi Status & Other selection criteria & $\begin{array}{c}\text { Population } \\
\text { (research date } \\
\text { 2006) }\end{array}$ & $\begin{array}{l}\text { Number of } \\
\text { employees }\end{array}$ \\
\hline $\begin{array}{l}\text { Local Administration (“A”) } \\
\text { (located in the metropolitan } \\
\text { area of Barcelona) }\end{array}$ & $\begin{array}{l}\text { Pi applied and } \\
\text { maintained for } \\
\text { more than } 15 \\
\text { years }\end{array}$ & $\begin{array}{c}\text { Latin American Award of Quality in } \\
\text { 2000, and a special mention of the } \\
\text { judging board of the EFQM, in the } \\
\text { same year }\end{array}$ & 46,079 & 296 \\
\hline $\begin{array}{l}\text { Local Administration "B" } \\
\text { (located in the } \\
\text { Autonomous Community } \\
\text { of Madrid) }\end{array}$ & $\begin{array}{c}\text { Pi applied } \\
\text { during } 20 \text { years }\end{array}$ & $\begin{array}{c}\text { The Local Administration "B" } \\
\text { obtained } 500 \text { points to be awarded } \\
\text { with the Gold Seal Award of the } \\
\text { EFQM in } 2004 .\end{array}$ & 107,098 & 1,140 \\
\hline $\begin{array}{l}\text { Local Administration "C" } \\
\text { (Capital of the } \\
\text { Autonomous Community } \\
\text { of Aragón) }\end{array}$ & $\begin{array}{l}\text { Pi applied for } \\
\text { at least } 10 \text { years }\end{array}$ & $\begin{array}{l}\text { Spanish local government that has } \\
\text { started and develops the application } \\
\text { of a quality system under the ISO } \\
9000 \text { standard, conducted in its } \\
\text { urban planning management. }\end{array}$ & 650,592 & $\begin{array}{l}5,000 \\
(550 \text { in the } \\
\text { management) }\end{array}$ \\
\hline $\begin{array}{l}\text { Local Administration } \\
\text { "D" (Capital of the Álava } \\
\text { Province in the Basco } \\
\text { Country) }\end{array}$ & $\begin{array}{c}\text { Resumption of } \\
\text { the PI }\end{array}$ & $\begin{array}{l}\text { Spanish local Administration that } \\
\text { has started the application of a } \\
\text { total quality program, temporarily } \\
\text { interrupted for various reasons, then } \\
\text { resumed. }\end{array}$ & 229,080 & 2,696 \\
\hline
\end{tabular}

CHART 2 - Studied local Administrations

Source: the author. 


\section{I Data collection}

The collection of data was conducted by using five methods: 1) direct observation; 2) nonintrusive participatory observation; 3) documental analysis; 4) in-depth semi-structured interviews; and 5) research diary, in this sequence.

Direct observation. The direct observation consisted of the conduction of trips and visits to the places where the operational work of the local Administration was developed. As observation procedure, the execution of work processes was focused, characterizing their limits and the process frontiers (start and end). Places through which some work processes pass were visited, from their entrances (Citizen Service Points, service Modules, Single Windows, remote Points, etc.), processing (offices, work areas, workshops, fire departments, storehouses), until their exit or service delivery (again the Citizen Service points). Photos were also taken to document the moments, situations, and basic facts under study.

Non-intrusive participatory observation.

In this research, approximately 52 field events centered in work meetings of the following types were observed under this method: 1) observation of the meetings of the process improvement teams, work or change groups, responsible for improving their work processes in their natural sphere and context, and 2) observation of quality or improvement coordinator staff meetings. The work sessions with the improvement teams were recorded, except when otherwise requested by such teams. In total, 10 hours of recording were obtained, which were subsequently transcribed and analyzed.

Documental Analysis. The necessary documental material is collected from each local Administration for the integration of the case, after conducting a direct observation of the facilities. 28 types of internal documents and 21 types of records were collected in the three local Administrations, including minutes, reports, quality and process improvement manuals, internal magazines, divulgation articles, material in homepages, and formation manuals, among others. This copied documentation allows establishing a rapport of each case, and a better understanding of the phenomenon under study (MERRIAM, 1998).

In-depth semi-structured interviews. A total of 28 interviews were conducted, including the Mayor and municipal managers, directors, coordinators and municipal servants involved in the PI effort; each interview had an average duration of 75 to 120 minutes, which were transcribed, by keeping a close contact via phone and e-mail with the participant actors to solve possible doubts and interpretations.

Research diary. Comprised of the notes taken in each contact, during the research process. This method was very important because it represented a source to guide and adjust the research when necessary. For instance, during the meetings with the improvement teams, when it was not possible to record, it was a useful took to make observations and to take note of any relevant information. Besides, it was a useful tool to generate reflections, informal comments and other basic elements when collecting the information (EISENHARDT, 1989).

\subsection{Data analysis}

For the analysis, a database and a matrix base were constructed, in addition to networks and tables of construction of the patterns obtained. Likewise, when all the evidence has been revised, analyzed and codified, a preliminary report of each study case was elaborated, and then submitted to the consideration of the main informants in each local Administration. The review of the first preliminary report of the study case not only helped to validate the data collection process, but also to identify possible gaps, and to obtain further data and patterns, reflections that were relevant for the study. Following the established research design, the comparison between cases were done through a cross-case analysis with the purpose of finding frequencies and/or coincidences in the 
concepts individually determined or differences that could be logically explained.

As the result of the comparative analysis, a sequence of evolving stages of the PI (using the process theory as basis - the horizontal analysis at the micro level - PETTIGREW, 1990, 1997) appeared. It is noteworthy that such research products, resulting from the comparative analysis of the studied cases, were again compared with the existing literature on the topic. The previous step was essential to increase the reliability of the investigation, taking the conclusions to the limit with the aim of establishing a more creative theoretical framework, which will really benefit the field of operations management in the public sphere. Therefore, this double-way work of the data obtained through the reference framework and the studied literature is regarded as an interactive process of qualitative investigation (PETTIGREW, 1997).

\section{RESULTS AND DISCUSSION}

To answer the question of How the Process Innovation is presented in a framework of Total Quality Management application in Spanish local Administrations? we can discuss and conclude at the light of the conceptual framework in two main contributions. The first contribution emerging from this section, according to the evidence found, is that the PI is presented in the management of local Administrations by means of the application of improvement activities ${ }^{5}$, which were integrated in a set of evolving stages in different application levels (see Chart 3).

Thus, four application levels were identified, starting in the precedent level of classical municipal management models (level 0 ), passing by a level 1 of discovering the PI, continuing to a level of deployment of the PI (level 2), until reaching a level of institutionalization (level 3) where the PI is converted into part of the municipal management, completing with a level of strategic connection and system improvement (level 4). In each of such levels, the common improvement activities that compose each evolving stage were identified. Within the comparative case analysis, we could also observe that the evolving stages and their improvement activities did not appear in the same degree in each local Administration. Each of the evolving stages and improvement activities is presented in a specific moment in the history of each local administration, or in a specific situation lived by such local administration in that moment in time. That is the reason why its application and evolution had a different relevance in each of those moments. Some examples of such improvement activities are the creation of improvement teams to solve the problems of public processes and services; the qualification of the administration staff in such themes; the creation of Quality and Innovation Committees, or according to the case, the development and self-evaluations and audits of the ISO 9000 standard or the EFQM.

As the second theoretical contribution, it was also possible to identify the application of different techniques and tools related to the PI around the implementation of the TQM. Thus, the local Administration "A" has gone through its evolution path from the PI of the Kaizen incremental type, with problemsolving methodologies and improvement teams; passing through process redesign methodologies, applying process maps and flowcharts; until using a model of self-evaluation and excellence such as the EFQM. On the other hand, the local Administration " $\mathrm{B}$ " has worked with organization, order and cleaning techniques in the working areas such as the $5 \mathrm{~S}$, service letters, and workshops to redesign processes. The local Administration " $C$ ", in turn, has shown the redesign of processes as the main PI technique, before their certification pursuant to the ISO 9000 standard. At last, the local Administration "D", after experimenting an interruption of its innovation effort until resuming it, has applied different techniques, such as problem-solving methodologies and improvement teams, as Kaizen 
workshops, 5S, service letters, and the first signs of an improvement suggestion system called: "Ideas in Action".

Comparing the results found (see Chart 3) with the theoretical framework, it is possible to say that the pace of application of a PI effort around the TQM in a public sphere, i.e., the generation of such improvement activities in the evolving stages, is slow, gradual and prolonged, opposed to the one in the private sector. Furthermore, the generation of such improvement activities in that pace is strongly influenced by some of the particularities of the public sector. Among the particularities almost directly influencing the pace of the PI application the following are included: 1) the influence of the political dimension, i.e., the guidelines, decisions and negotiations in this sphere, influence the time of application of the PI. In addition, there is also 2) an influence generated by the cultural work environment, derived from the organizational structures that follow the classic bureaucratic model, which creates certain coordination, communication and information flow malfunctions, as well as power struggles at the time of application. And finally, with 3) the strong emphasis on legal requirements compliance (inputs focus) and rules compliance, which can delay or interrupt the application of the PI effort under the TQM focus (MOORE, 2005; RAMIO-MATAS, 1999; SANER, 2002).

For this reason, the PI application we could observe in the sphere of the studied local Administrations takes place in a slow and gradual pace, which can take some years. A different feature in comparison to the literature found both in the United Kingdom and the USA, with projects such as the NPM, or the NPR in the United States of America (BERMAN; WEST, 1995; POLLIT, 1994). In addition, the result found from the improvement activities in the PI application under the context of the TQM was also characteristic of this work for the occidental
(PRAJOGO; SOHAL, 1994) and Latin American literature on the theme of the public sector, since the empirical works found in Andreu, Ricart and Valor (1996); Albizu, Olazarán and Simón (2004); Suárez-Barraza and Ramis-Pujol (2010), always refer to the PI application through isolated improvement projects, of short duration, which are conducted by consultants, and who do not manage to consolidate improvement activities that create evolving stages along time. Certainly the author accepts that it is necessary to deepen even more the empirical work with other local administrations, in other contexts and in other countries to be able to generalize the results found. Thus, the studied local administrations have supported their management models in elements such as patience and constancy, with the purpose of improving. Two basic elements that have been necessary to allow waiting for the necessary political and technical moments that led them to the application of the PI.

At last, the management models, the techniques and tools found are similar to what is reported in the PI and TQM literature in the public sector (ALBIZU; OLAZARÁN; SIMÓN, 2004; ANDREU; RICART; VALOR, 1996; LOOMBA; SPENCER, 1997; SUÁREZBARRAZA; RAMIS-PUJOL, 2010). However, the characteristic of this research result is that each of the previous elements (management models, techniques and tools) were applied in a context of improvement activities that helped to consolidate and to understand in detail its implementation. The empirical evidence has shown us during the interviews that both the managers and the municipal employees showed a higher degree of understanding about the models, techniques and tools of the PI when these were applied under the context of the improvement activities.

The results are presented in the following Chart 3: 


\begin{tabular}{|c|c|c|c|c|}
\hline $\begin{array}{l}\text { Cases/ } \\
\text { Elements }\end{array}$ & $\begin{array}{l}\text { Local Administration } \\
\text { "A" }\end{array}$ & $\begin{array}{l}\text { Local Administration } \\
\text { "B" }\end{array}$ & $\begin{array}{l}\text { Local Administration } \\
\text { "C" }\end{array}$ & $\begin{array}{c}\text { Local } \\
\text { Administration " } D \text { " }\end{array}$ \\
\hline \multirow[t]{2}{*}{$\begin{array}{l}\text { Stages of } \\
\text { application } \\
\text { of the } \\
\text { process } \\
\text { innovation }\end{array}$} & $\begin{array}{l}\text { Five stages that emerged } \\
\text { 1. Management-work } \\
\text { focus per departmental } \\
\text { function } \\
\text { (Level } 0=\text { Classical } \\
\text { models) } \\
\text { 2. Basic elements of the } \\
\text { continuous improvement } \\
\text { (Level } 1=\text { Discovering PI) } \\
\text { 3. "Classical" of } \\
\text { management by total } \\
\text { quality, excellence and } \\
\text { improvement } \\
\text { (Level } 2=P I \text { Deployment) } \\
\text { 4. System and/or } \\
\text { management model focus } \\
\text { per process } \\
\text { (Level } 3=P I \\
\text { institutionalization) } \\
5 . \text { Focus of strategic } \\
\text { connection to the } \\
\text { continuous improvement } \\
\text { of processes (Level } 4= \\
\text { strategic connection of } \\
\text { the PI) }\end{array}$ & $\begin{array}{l}\text { Three stages that } \\
\text { emerged } \\
\text { Started from a prior } \\
\text { stage before applying } \\
\text { the PI (Level } 0= \\
\text { Classical models) } \\
\text { Stage of management } \\
\text { modernization } \\
\text { (Level } 2=P I \\
\text { Deployment) } \\
\text { 2. Stage of development } \\
\text { and integration } \\
\text { of the quality in } \\
\text { the management } \\
\text { system(Level } 3=P I \\
\text { institutionalization) } \\
\text { 3. Stage of } \\
\text { improvement and } \\
\text { innovation: for an } \\
\text { intelligent local } \\
\text { administration } \\
\text { (Level } 4=\text { strategic } \\
\text { connection of the PI) }\end{array}$ & $\begin{array}{l}\text { Three stages that } \\
\text { emerged } \\
\text { Started from a prior } \\
\text { stage before applying } \\
\text { the PI (Level } 0= \\
\text { Classical models) } \\
\text { 1. Initial stage of } \\
\text { misrule } \\
\text { (Level } 1= \\
\text { Discovering PI) } \\
\text { 2. Stage of application } \\
\text { of the quality } \\
\text { and continuous } \\
\text { improvement } \\
\text { model (Level } 2=P I \\
\text { Deployment) } \\
\text { 3. Stage of } \\
\text { consolidation and new } \\
\text { challenges } \\
\text { (Level } 3=P I \\
\text { institutionalization) } \\
\text { *Sporadic presence }\end{array}$ & $\begin{array}{l}\text { Three stages that } \\
\text { emerged } \\
\text { 1. Stage of the "Lost } \\
\text { opportunity" } \\
\text { (Level } 0 \text { = Classical } \\
\text { models) } \\
\text { Period of deadlock or } \\
\text { interrupted effort } \\
\text { (Blockage) } \\
\text { 2. Stage of continuous } \\
\text { process improvement } \\
\text { per demand (Level } \mathbf{1} \\
=\text { Discovering PI) } \\
\text { 3. Stage of pursuit of } \\
\text { a integral excellence } \\
\text { model (Level } 2=\boldsymbol{P I}\end{array}$ \\
\hline & $\begin{array}{l}\text { - Creation of } \\
\text { improvement teams } \\
\text { - Qualification of staff } \\
\text { - Development of quality } \\
\text { plans } \\
\text { - Development and } \\
\text { application of redesign } \\
\text { methodologies } \\
\text { - Creation of PI } \\
\text { committees } \\
\text { - Development of } \\
\text { strategic and operational } \\
\text { plans connected to the PI } \\
\text { - Self-evaluations and/ } \\
\text { or external audits } \\
\text { (EFQM, ISO 9000, } \\
\text { Iberoamericano) }\end{array}$ & $\begin{array}{l}\text { - Creation of } \\
\text { improvement teams } \\
\text { - Qualification of staff } \\
\text { - Development of } \\
\text { quality plans } \\
\text { - Development and } \\
\text { application of redesign } \\
\text { methodologies } \\
\text { - Creation of PI } \\
\text { committees } \\
\text { - Self-evaluations and/ } \\
\text { or external audits } \\
\text { (EFQM, ISO 9000, } \\
\text { Iberoamericano) }\end{array}$ & $\begin{array}{l}\text { - Application of a } \\
\text { Quality system based } \\
\text { on the Standard ISO } \\
9000 \\
\text { - Development of } \\
\text { process measurement } \\
\text { indicators } \\
\text { - Qualification of staff } \\
\text { - Creation of } \\
\text { improvement groups } \\
\text { - Workshops of process } \\
\text { redesign }\end{array}$ & $\begin{array}{l}\text { - Qualification } \\
\text { focused on the } \\
\text { individual quality. } \\
\text { - History of Quality } \\
\text { (combined with } \\
\text { redesign techniques) } \\
\text { - Application of the } \\
\text { 5S. } \\
\text { - Application of the } \\
\text { Service Letters. } \\
\text { - Development of a } \\
\text { suggestion system } \\
\text { (Ideas in action). }\end{array}$ \\
\hline $\begin{array}{l}\text { Models of } \\
\text { quality and } \\
\text { excellence }\end{array}$ & $\begin{array}{l}\text { - EFQM } \\
\text { - Process Innovation of } \\
\text { the Kaizen type } \\
\text { - Process Innovation of } \\
\text { the redesign type }\end{array}$ & $\begin{array}{l}\text { - EFQM } \\
\text { - Process Innovation of } \\
\text { the Kaizen type } \\
\text { - Process Innovation of } \\
\text { the redesign type }\end{array}$ & $\begin{array}{l}\text { - ISO } 9000 \\
\text { - Process Innovation of } \\
\text { the redesign type }\end{array}$ & $\begin{array}{l}\text { - Process Innovation } \\
\text { of the Kaizen type }\end{array}$ \\
\hline $\begin{array}{l}\text { Techniques } \\
\text { and tools } \\
\text { of process } \\
\text { innovation }\end{array}$ & $\begin{array}{l}\text { - History of quality } \\
\text { - } 5 S \text { and process maps } \\
\text { - Redesign methodology } \\
\text { - Improvement teams } \\
\text { - Self-evaluations EFQM }\end{array}$ & $\begin{array}{l}\text { - Redesign } \\
\text { methodology } \\
\text { - } 5 \text { S and Gemba-Kaizen } \\
\text { workshops } \\
\text { - Service Letters } \\
\text { - Improvement Groups }\end{array}$ & $\begin{array}{l}\text { - Redesign } \\
\text { methodology } \\
\text { - Improvement Groups } \\
\text { - Process indicators }\end{array}$ & $\begin{array}{l}\text { - Kaizen type } \\
\text { workshops } \\
\text { - 5S } \\
\text { - Service Letters } \\
\text { - Suggestion system }\end{array}$ \\
\hline
\end{tabular}

CHART 3 - Evolving stages, improvement activities and PI techniques of the studied local administrations with the TQM framework

Source: the author. 
To answer the second question of the research What is the impact of the Process Innovation in public services in the framework of the Total Quality Management application in Spanish local
Administrations? The empirical evidence is shown through the following chart extracted from the documental evidence of the local administrations.

\begin{tabular}{|c|c|c|c|c|c|c|}
\hline $\begin{array}{c}\text { Measurements/ } \\
\text { Local } \\
\text { Administration }\end{array}$ & Intern & $\begin{array}{r}\text { ial performance } \\
\text { Average fu }\end{array}$ & $\begin{array}{l}\text { of the local admi } \\
\text { llfillment of the st } \\
(2000-2005)\end{array}$ & $\begin{array}{l}\text { nistration pro } \\
\text { tandards }\end{array}$ & & $\begin{array}{c}\text { Citizen } \\
\text { satisfaction }\end{array}$ \\
\hline Processes & $\begin{array}{c}\text { Urban } \\
\text { development }\end{array}$ & $\begin{array}{c}\text { Public way } \\
\text { maintenance }\end{array}$ & $\begin{array}{c}\text { Social } \\
\text { development }\end{array}$ & $\begin{array}{c}\text { Public } \\
\text { security }\end{array}$ & $\begin{array}{l}\text { Citizen } \\
\text { service }\end{array}$ & Average \\
\hline $\begin{array}{l}\text { Local } \\
\text { Administration } \\
\text { “A" } \\
\text { (Each local } \\
\text { administration } \\
\text { has different } \\
\text { standards for each } \\
\text { process) }\end{array}$ & \begin{tabular}{|l|} 
Standard \\
Solid waste \\
collection every \\
day of the year at \\
the same time \\
$(\mathbf{9 4 . 1 \% )}$
\end{tabular} & $\begin{array}{l}\text { Standard } \\
\text { Repair } \\
\text { damages in } \\
\text { streets and } \\
\text { avenues, at } \\
\text { most within } \\
72 \text { hours } \\
(\mathbf{8 6 . 9 5 \% )}\end{array}$ & $\begin{array}{l}\text { Standard } \\
\text { Conduct the } \\
\text { first attention } \\
\text { in social services } \\
\text { within at most } \\
48 \text { hours } \\
(\mathbf{8 1 . 4 \% )}\end{array}$ & $\begin{array}{l}\text { Standard } \\
\text { Conduct } \\
\text { immediate } \\
\text { intervention, } \\
\text { maximum } \\
\text { within 5 } \\
\text { minutes } \\
(\mathbf{9 4 . 5 \% )}\end{array}$ & $\begin{array}{l}\text { Standard } \\
\text { Serve the } \\
\text { citizen with } \\
\text { a maximum } \\
\text { waiting time } \\
\text { of } 5 \text { minutes } \\
(\mathbf{9 5 . 9 \% )}\end{array}$ & $\begin{array}{l}\text { Measurement of } \\
\text { the global citizen } \\
\text { satisfaction as } \\
\text { a perception } \\
\text { of the local } \\
\text { administration } \\
\text { management } \\
(\mathbf{6 . 5 3 )} 1 \text {, in } 11 \text { years } \\
\text { of measurement, } \\
\text { period } 1990-2007 \\
\text { (each two years) }\end{array}$ \\
\hline $\begin{array}{l}\text { Local } \\
\text { Administration } \\
\text { “B” } \\
\text { (The local } \\
\text { administration } \\
\text { does not have } \\
\text { process standards) }\end{array}$ & $\begin{array}{l}\text { Process improved } \\
\text { in } \mathbf{9 2 \%} \text {, } \\
\text { through redesign } \\
\text { methodologies }\end{array}$ & $\begin{array}{l}\text { Design and } \\
\text { construction } \\
\text { process of a } \\
\text { polisports field } \\
(\mathbf{8 8} \%)\end{array}$ & $\begin{array}{l}\text { Process } \\
\text { improved in } \\
\mathbf{7 8 \%}, \text { through } \\
\text { redesign } \\
\text { methodologies }\end{array}$ & $\begin{array}{l}\text { The process } \\
\text { improvement } \\
\text { was not } \\
\text { worked out }\end{array}$ & $\begin{array}{l}\text { Process } \\
\text { improved in } \\
\mathbf{8 2 \%} \text {, through } \\
\text { redesign }\end{array}$ & $\begin{array}{l}\text { Measurement of } \\
\text { the global citizen } \\
\text { satisfaction as } \\
\text { a perception } \\
\text { of the local } \\
\text { administration } \\
\text { management } \\
\text { (7.1) } 2 \text {, in } 3 \text { years } \\
\text { of measurement, } \\
\text { period 2003-2005 } \\
\text { (annual) }\end{array}$ \\
\hline $\begin{array}{l}\text { Local } \\
\text { Administration } \\
\text { "C" } \\
\text { (Let's remember } \\
\text { that this local } \\
\text { administration } \\
\text { has only } \\
\text { implemented } \\
\text { it in the urban } \\
\text { planning } \\
\text { management) }\end{array}$ & \begin{tabular}{|l|} 
- Management \\
of urban licenses \\
for smaller works \\
$(\mathbf{8 6 \%})$ \\
- Management \\
of work \\
construction \\
licenses \\
$(\mathbf{9 8 \% )}$ \\
- Management of \\
bigger work and \\
new construction \\
licenses \\
$(\mathbf{6 1 \% )}$ \\
\end{tabular} & $\begin{array}{l}\text { The process } \\
\text { improvement } \\
\text { was not } \\
\text { worked out }\end{array}$ & $\begin{array}{l}\text { The process } \\
\text { improvement } \\
\text { was not worked } \\
\text { out }\end{array}$ & $\begin{array}{l}\text { The process } \\
\text { improvement } \\
\text { was not } \\
\text { worked out }\end{array}$ & $\begin{array}{l}\text { The process } \\
\text { improvement } \\
\text { was not } \\
\text { worked out }\end{array}$ & $\begin{array}{l}\text { Measurement of } \\
\text { the global citizen } \\
\text { satisfaction as } \\
\text { a perception } \\
\text { of the local } \\
\text { administration } \\
\text { urban planning } \\
\text { management } \\
\text { (3.88) 3, in } 3 \text { years } \\
\text { of measurement, } \\
\text { period 2003-2005 } \\
\text { (every year) }\end{array}$ \\
\hline $\begin{array}{l}\text { Local } \\
\text { Administration } \\
\text { "D" } \\
\text { (The local } \\
\text { administration } \\
\text { does not have } \\
\text { process standards) }\end{array}$ & $\begin{array}{l}\text { The process } \\
\text { improvement } \\
\text { was not worked } \\
\text { out }\end{array}$ & $\begin{array}{l}\text { The process } \\
\text { improvement } \\
\text { was not } \\
\text { worked out }\end{array}$ & $\begin{array}{l}\text { Process } \\
\text { improved } \\
\text { through the } \\
5 \mathrm{~S} \text { in } \\
95 \%\end{array}$ & $\begin{array}{l}\text { The process } \\
\text { improvement } \\
\text { was not } \\
\text { worked out }\end{array}$ & $\begin{array}{l}\text { Added value } \\
\text { process } \\
\text { (Finances) } \\
\text { improved in } \\
\mathbf{9 2 \%} \text { through } \\
\text { Kaizen } \\
\text { workshops } \\
\end{array}$ & $\begin{array}{l}\text { It was not } \\
\text { measured. }\end{array}$ \\
\hline
\end{tabular}

CHART 4 - Summary of some PI impacts on the local administrations management

Source: the author.

*Memories and information systems of each local administration, as well as the documental analysis and interviews. It is noteworthy that the percentages of the individual process performance is an average of the different years in which it was measured.

Notes: (1)(2) Citizen satisfaction scale of 0 (not satisfied at all) to 10 (totally satisfied) (3) Citizen satisfaction scale of 0 (not satisfied at all) to 5 (totally satisfied) 
As shown in Chart 4, the result of the sustained application of the Process Innovation under a context of TQM along the years has allowed to the local administrations certain impacts on the internal performance of the municipal management, as well as on the levels of satisfaction of the citizen who is served in each municipality. The Local Administration "A" has determined an operation standard for the public way maintenance process that indicates the need of repairing damages in streets and avenues within at most 72 hours. The average fulfillment of this standard in the period $2000-2005$ was $86.25 \%$ out of the possible $100 \%$. The measurement of such percentages was conducted through a citizen survey with the fulfillment scale of $100 \%$ of the indicated standard. Local administrations have outsourced the measurement to keep the objectivity. Therefore, if the result is close to $100 \%$, this indicates that the defined standard was achieved for each public service.

On the other hand, the Local Administration " $B$ ", " $C$ " and " $D$ " have not used operation standards. Nevertheless, their measurement process was the percentage of progress of the process redesign techniques application to improve the process. For example, in the Local Administration " $\mathrm{B}$ ", in its design and construction process of a multi-sports field, the process progress improved $88 \%$; while in the Local Administration " $C$ ", the management process of work construction licenses had a progress of $98 \%$. At last, according to Chart 4, evidences were also found indicating that the PI is directly applied with small adaptations of language and incorporation (development of specific methodologies), in the studied cases. This result confirms what Mayordomo (1990) has highlighted when saying that the management techniques, such as the Operation Guidance, which include the PI, can be applied in a direct manner in the public sector. Another result emerging from this research, which goes beyond what was found in the literature, was that the PI was not only applied in a direct manner, but also the improvements obtained by it could be sustained throughout time.

\section{CONCLUSIONS AND FINAL CONSIDERATIONS}

The turbulent environment of the economic and financial crisis in Europe that has strongly affected Spain in the past years transforms in priority the cost saving issue in local Administrations, regardless of the political "color" of the governing group. As we could observe in our research, any activity that represents a waste or an expenditure, a Muda, as called by the Japanese, will lead any local Administration to start a gradual transformation of a "wasteful" public organization, which provides low quality, highly costly and extremely slow services, and mainly, little sensitive to the needs and demands of the citizens. In a scenario as the current one, this phenomenon would be really risky to manage in any Spanish local administration.

On the other hand, as suggested by some authors, perhaps the theme of quality, which had its boom and peak in Spain in the period 1995-2008 (CASADESÚS; HERAS, 2005), also in the public sector (PALACÍN-SAENS, 2000), is giving place to new management approaches such as the Process Innovation, based on the Kaizen philosophy of continuous improvement (SUÁREZ-BARRAZA, 2007). We don't say that this management approach is the panacea that can solve all the problems of a local government. Nevertheless, the evidence found in those cases has indicated us that when there was a pursuit, and committed politicians and technical managers willing to innovate their management and work processes, such change effort was actually done, with the application of PI techniques and tools in a direct way, with very few adaptations in regard to the application in the private sector, with a positive impact on certain elements of their internal management, and external impact on the citizen satisfaction level (see Chart 4). Therefore, patience is perhaps one of the fundamental values to consolidate it, since the application and evolution of the PI take place through a series of evolving stages and improvement activities, in a slow and gradual pace, always expecting the opportune political moment to carry them out. 
At last, we can conclude that the biggest challenge of local Administrations nowadays is not to start an innovation effort or initiative to face the "crisis", but rather to sustain it in the long run, so that such effort can actually penetrate in the routine management, generating benefits for the public organization and to all the stakeholders. Since the whole investigation is based on a qualitative focus using the study case method, this article has some limitations. Firstly, everything is sustained on a qualitative work. Another difficulty is to objectively handle the large amount of data generated during the field work, making it difficult to appraise all the relations that could exist in the studied phenomenon (EISENHARDT, 1989). Finally, because of the nature of the study, the impact of the PI application on public services was not quantitatively appraised (questionnaires designed by the researchers); instead of that, the data from the local administrations documental evidence were used. Therefore, it is not possible to directly attribute the relation that might possibly exist between the PI application and the impacts on public services at the local administrations. However, in comparison to other studies in the literature, those local administrations that did not conduct any effort of the kind have not achieved such impacts on the public services they offer (CASADESÚS; HERAS, 2005; PALACÍNSAENS, 2000; RAMIO-MATA, 1999). Despite those limitations, our study contributes to the existing literature through an empirical work that shows the methodological relations and their specific application. The study can obviously be extended to other local administrations in other Latin American countries to corroborate such findings.

\section{NOTAS}

1. The word "Client" in Public Administration continues to be a very controversial topic, as the result of the various roles that could be played by the citizens in their relations with the public organization (SWISS, 1992).

2. The study sample was 258 Local administrations that cover a population of more than 10,000 residents.
3. Acronym in English of European Foundation of Quality Management

4. The pioneer Local administrations have been Alcobendas (in the community of Madrid); Esplugues de Llobregat (in Cataluña); Logrońo (in la Rioja); Valladolid, Vitoria-Gasteiz (in the Vasco country) among others. It is possible to see the works of Giner-Rodríguez (1998) and FEMP (1999).

5. An improvement activity can be defined as: "a unit of the process that can conduct a work (material or mental) in which the status quo of the unit can be changed".

\section{REFERENCES}

ALBIZU, E.; OLAZARAN, M.; SIMÓN, K. Reingeniería de procesos en Espańa: la adaptación de una moda de gestión. Revista de Dirección y Administración de Empresas, San Sebastián, n. 11, p. 161-181, marzo 2004.

ANDREU, R.; RICART, J.; VALOR, J. Innovación de procesos y cambio organizativo. Harvard Deusto Business Review, Barcelona, n. 70, p. 24-37, 1996.

BATEMAN, N. Sustainability: the elusive element of process improvement. International Journal of Operations \& Production Management, Bradford, v. 25, n. 3, p. 261-276, 2005.

; DAVID, A. Process Improvement programmes: a model for assessing sustainability. International Journal of Operations \& Production Management, Bradford, v. 22, n. 5 , p. 515-526, 2002.

BARZELAY, M.; ARMAJANI, B. J. Breaking through bureaucracy: a new vision for managing in government. Berkeley: University of California Press, 1992.

BERMAN, E.; WEST, B. Municipal commitment to total quality management: a survey of recent progress. Public Administration Review, Washington, D. C., v. 55, n. 1, p. 57-66, 1995.

BESSANT, J.; CAFFYN, S. High-Involvement innovation through continuous improvement. International Journal Technology Management, Atlanta, v. 14, n. 1, p. 7-28, 1997. 
CASADESÚS, M.; HERAS, I. El boom de la calidad en las empresas españolas. Universia Business Review, Madrid, n. 7, Tercer Trimestre, p. 2-13, 2005.

CHANG, R. Continuous process improvement: a practical guide to improving processes for measurable results. London: Kogan Page, 1995.

DAVENPORT, T. H. Process innovation: reengineering work through information technology. Boston: Harvard Business School Press, 1993.

DEMING, W. E. Out of the crisis. Cambridge: MIT/CAES, 1986.

DÍAZ-MÉndEZ, A. Auto-evaluación EFQM y obtención del sello de excelencia en el ayuntamiento de alcobendas. 2007. 18 p. Ponencia presenteada en Esade Business School, del Módulo de Operaciones y Calidad, del Master de Dirección y Gestión Pública de Esade Business School, Madrid, España, 2007.

EISENHARDT, K. M. Building theories from case study research. Academy of Management Review, Briarcliff Manor, v. 14, n. 4, p. 532-550, 1989.

FARAZMAND, A. Editor's note: public organizations in the age of accelerated globalization. Public Organization Review, Dordrecht, v. 1, n. 1, p. 5-13, 2001.

FEDERACIÓN ESPAÑOLA DE MUNICIPIOS Y PROVINCIAS - FEMP. Consideraciones sobre la calidad en la administración local. Madrid, abr. 1999.

; ASOCIACIÓN ESPAÑOLA PARA LA CALIDAD - AEC. Informe acerca de la encuesta sobre los servicios de atención a la ciudadanía. Madrid, 2005.

FERRÉ-BARGALLO, J. M. La gestión y mejora de procesos en el ayuntamiento de Esplugues de Llobregat. Ponencia presenteada en Esade Business School, del Módulo de Operaciones y Calidad, del Master de Dirección y Gestión
Pública de Esade Business School, Madrid, España, 2007.

GARVIN, D. A. The processes of organization and management. Sloan Management Review, Cambridge, v. 39, n. 4, p. 33-50, 1998.

GINER-RODRÍGUEZ, E. La introducció d' un sistema gerencial: el caso de l' adjuntament d' Esplugues de Llobregat. Comunicacions de la Diputació de Barcelona, Barcelona, n. 13, p. $1-5,1998$.

HAMMER, M. Process audit. Harvard Business Review, Boston, p. 111-123, Apr. 2007.

\section{; CHAMPY, J. Reengineering the}

corporation: a manifesto for business revolution. New York: Harper Business, 1993.

HARKNESS, W.; KETTINGER, W.; SEGARS, A. Sustaining process improvement and innovation in the information services function: lessons learned at the bose corporation. MIS Quarterly, Minneapolis, v. 20, n. 3, p. 349-368, Sept. 1996.

HARRINGTON, H. J. Business process improvement: the breakthrough strategy for total quality, productivity and competitiveness. New York: McGraw-Hill, 1991.

LEE, R. G.; DALE, B. G. Business process management: a review and evaluation. Business Process Management Journal, Bradford, v. 4, n. 3, p. 214-223, 1998.

LOOMBA, A.; SPENCER, M. A model for institutionalizing TQM in a state government agency. International Journal of Quality \& Reliability Management, Bradford, v. 14, n. 8, p. 753-767, 1997.

MACDONALD, J. Together TQM and BPR are winners. TQM Magazine, Bradford, v. 7, n. 3, p. 21-25, 1995.

MARTÍN-CASTILLA, J. I. et al. Guías de apoyo a la calidad en la gestión pública local: planes de calidad, innovación y modernización 
en las administraciones locales - guía 2. Madrid: Ministerio de Administraciones Públicas, 2005.

MAYORDOMO, X. M. Técnicas gerenciales y modernización de la administración pública en España. Documentación Administrativa, Madrid, n. 223, jul./sept. 1990.

MCADAM, R.; DONAGHY, J. Business process re-engineering in the public sector: a study of staff perceptions and critical success factors. Business Process Management Journal, Bradford, v. 5, n. 1, p. 33-41, 1999.

MERRIAM, S. Qualitative research and case study applications in education. San Francisco: Jossey-Bass Publishers, 1998.

MILAKOVICH, M. Total quality management in the public sector. National Productivity Review, San Francisco, CA, v. 10, n. 2, p. 195-213, Spring 1991.

MOORE, M. H. Break-through innovations and continuous improvement: two different models of innovative processes in the public sector. Public Money \& Management, Oxford, v. 25, n. 1, p. 43-50, 2005.

MOYADO-ESTRADA, F. Gestión pública y calidad: hacia la mejora continua y el rediseño de las instituciones del sector público. En: CONGRESO INTERNACIONAL DEL CLAD SOBRE LA REFORMA DEL ESTADO Y DE LA ADMINISTRACIÓN PÚBLICA, 7., 2002, Lisboa. Proceedings... Lisboa: CLAD, 2002.

OLÍAS DE LIMA, B. Rendimiento institucional, ética y democracia. En: DÍAZ-MÉNDEZ, A.; CUElLAR-MARTÍN, E. (Coord.). Administración inteligente. Madrid: Agencia de Evaluación y Calidad, MAP y Ayuntamiento de Alcobendas, 2007, p. 179-195.

OSBORNE, D.; GAEBLER, T. La reinvención del gobierno: la influencia del espíritu empresarial en el sector público. Barcelona: Paidós Ibérica, 1994. (Paidós Estado y Sociedad, 22).
PALACÍN-SAENS, B. Aseguramiento de calidad en el ayuntamiento de Logroño. Ayuntamiento de Logrońo, 2000.

PALMBERG, K.; GARVARE, R., Sustained quality management: how to receive the swedish quality award twice. International Journal of Quality \& Reliability Management, Bradford, v. 23, n.1, p. 42-59, 2006.

PETTIGREW, A. M. Longitudinal field research: theory and practice. Organization Science, Linthicum, v. 1, n. 3, p. 267-292, 1990.

What is a processual analysis? Scandinavian Journal of Management, Oxford, v. 13, n. 4, p. 337-348, 1997.

POLLIT, C. The citizen's charter: a preliminary analysis. Public Money \& Management, Oxford, v. 14, n. 2, pp. 23-35, 1994.

PRAJOGO, D.; SOHAL, A. The sustainability and evolution of quality improvement programmes: an Australian case study. Total Quality Management \& Business Excellence, Abingdon, v. 15, n. 2, p. 205-220, Mar. 2004.

RAMIO-MATAS, C. Desenvolupament organitzatiu de l'ajuntament. En:

LONGO, F. L'ajuntament gerencial: reflexions i propostes per gerencialitzar. Barcelona: Diputació de Barcelona, 1999. p. 43-74.

SANER, R. Quality assurance for public administration: a consensus building vehicle. Public Organization Review, Dordrecht, v. 2, n. 4, p. 407-415, 2002.

SALGUEIRO, A. Cómo mejorar los procesos y la productividad. Madrid: AENOR, 1999.

SENSENBRENNER, J. Quality comes to city hall. Harvard Business Review, Boston, n. 69, p. 64-75, 1991.

STRINGHAM, S. H. Does quality management work in the public sector? Public Administration and Management, Middletown, v. 9, n. 3, p. $182-211,2004$. 
SUÁREZ-BARRAZA, M. F. El Kaizen: la filosofía de mejora continua e innovación incremental detrás de la administración por calidad total. México: Panorama Editorial, 2007.

; MIGUEL-DÁVILA, J.A. En la búsqueda de un espacio de sostenibilidad: un estudio empírico de la aplicación de la mejora continua de procesos en ayuntamientos españoles. INNOVAR, Bogotá, v. 19, n. 35, p. 47-64, sept./dic. 2009.

; RAMIS-PUJOL, J. Implementation of Lean-Kaizen in the human resource service process: a case study in a mexican public service organization. Journal of Manufacturing
Technology Management, Bradford, v. 21, n. 3, p. 388-410, 2010.

SWISS, J. E. Adapting Total Quality Management (TQM) to government. Public Administration Review, Washington, D.C., v. 52, n. 4, p. 7-18, 1992.

YIN, R. Case study research: design and methods. Thousands Oaks: Sage Publications, 2003.

ZAIRI, M. Business process management: a boundaryless approach to modern competitiveness. Business Process Management Journal, Bradford, v. 3, n. 1, p. 64-80, 1997. 